\title{
PENGARUH ATRAKSI PARIWISATA TERHADAP PEMBERDAYAAN MASYARAKAT DI PANTAI CIMAJA CIKAKAK SUKABUMI
}

\author{
Oleh: \\ Lia Afriza, Holili Abadi \\ STIEPAR Yapari Aktripa Bandung \\ Program Studi Manajemen Pariwisata
}

\begin{abstract}
ABSTRAK
Penelitian ini berjudul pengaruh atraksi pariwisata terhadap pemberdayaan masyarakat di pantai Cimaja Cikakak Sukabumi. Terdapat tiga tujuan dari penelitian ini. Pertama, mengukur tingkat daya tarik turis di pantai Cimaja. Kedua, mengukur tingkat pemberdayaan masyarakat di pantai Cimaja. Ketiga, menganalisa efek daya tarik turis terhadap pemberdayaan masyarakat di Cimanja Cikakak Sukabumi dalam hal daya tarik turis, fasilitas dan aksesibilitas. Metode yang digunakan dalam penelitian ini adalah dengan menggunakan pendekatan desktiptif dan kuantitatif. Data diperoleh melalui observasi, interview, kuesioner, dan menggunakan skala likert dokumentasi. Sementara itu, sampel yang digunakan adalah teknik sampel incidental sejumlah 100 responden. Analisisi data dalam penelitian ini meliputi regresi multiple analisis, penentuan koefisien, F-test dan T-test. Seluruh variabel daya tarik turis memiliki efek terhadap pemberdayaan tetapi tidak signifikan. Berdasarkan hasil ketiga tujuan penelitian, dapat disimpulkan bahwa tujuan dari pertanyaan pertama mengenai daya tarik turis di pantai Cimaja sudah termasuk kedalam kategori "baik". sedangan, pemberdayaan masyarakat di pantai Cimaja termasuk kedalam kategori "sangat baik". Pertanyaan terakhir mengenai pengaruh daya tarik turis ditemukan 2,7\% tidak berefek signifikan dan $97,3 \%$ berpengaruh oleh faktor lain dalam pemberdayaan masyarakat di pantai Cimaja Cikakak Sukabumi.
\end{abstract}

Kata Kunci: Daya Tari Turis, Pemberdayaan Masyarakat. 


\title{
THE INFLUENCE OF TOURISM ATTRACTION TOWARDS COMMUNITY EMPOWERMENT IN CIMAJA CIKAKAK BEACH $S U K A B U M I$
}

\begin{abstract}
The research is titled The Influence of Tourism Attraction towards Community Empowerment in Cimaja Cikakak Beach Sukabumi. There are three purposes of the reserach. First, to measure the level of tourist attraction in Cimanja Beach. Second, to measure the level of community empowerment in Cimaja Beach. Third, to analyze the effect of tourist attraction towards community empowerment in Cimaja Cikakak Sukabum in terms of tourist attractions, emenities (facilities), and accessibility. The method in this research is descriptive with quantitative approach. The data was collected by observation, interviews, questionnaires, and documentation using likert scale. While the sampling method used was incidental sampling techniques as much as 100 respondents. The analysis used in this research include: multiple regression analysis, the coefficient of determination, F-test and T-test. All tourist attraction variabel have an effect on empowerment but not significant. Based on the results of the three objectives of research, it can be concluded that the purpose of the first research a tourist attraction in Cimaja Beach is in "good" category, the second research of community empowerment in Cimaja Beach "very good" category, and the third research a tourist attraction has no siginificant effect in the amount of 2,7\% and $97,3 \%$ influenced by other factors in community empowerment in Cimaja Cikakak Beach Sukabumi.
\end{abstract}

Key words: Tourist Attraction, Community Empowerment

\section{PENDAHULUAN}

\section{Latar Belakang Masalah}

Pariwisata merupakan salah satu sektor ekonomi yang dapat meningkatkan perekonomian daerah sehingga pada gilirannya dapat meningkatkan kesejahteraan masyarakat. Penyelenggaraan kegiatan kepariwisataan tidaklah terlepas dari sumber daya yang dimiliki dan keterlibatan para stakeholder dan sektor ekonomi lainnya untuk mendukung keberhasilan suatu pengembangan pariwisata.

Pada saat ini, kedudukan sektor pariwisata menjadi salah satu sektor andalan yang dapat meningkatkan devisa negara sebagai pendukung komoditi ekspor migas maupun non migas. Pengembangan sektor pariwisata dilakukan karena mampu memberikan kontribusi yang cukup besar bagi penerimaan devisa negara, dan disamping itu kegiatan pariwisata merupakan hal yang terkait erat dengan 
sumberdaya yang unik dari suatu tujuan wisata yaitu dalam bentuk daya tarik alam dan daya tarik budaya.

Indonesia memiliki banyak potensi dan sumber daya alam yang belum dikembangkan secara maksimal, termasuk didalamnya di sektor pariwisata. Untuk lebih memantapkan pertumbuhan sektor pariwisata dalam rangka mendukung pencapaian sasaran pembangunan, sehingga perlu diupayakan pengembangan produk-produk yang mempunyai keterkaitan dengan sektor pariwisata.

Di antara sekian banyaknya obyek wisata bahari di Indonesia, salah satunya adalah Kabupaten Sukabumi yang memiliki banyak obyek wisata bahari yaitu Pantai Cimaja. Pantai Cimaja berada di daerah Palabuhanratu, tepatnya berlokasi di Desa Cimaja Cikakak, Kecamatan Cikakak, Kabupaten Sukabumi, Provinsi Jawa Barat. Pantai Cimaja dihimpit oleh dua sungai yaitu sungai Cimaja dan sungai Cihaur, yang menjadikan Pantai Cimaja memiliki ombak yang berbeda dengan pantai yang lainnya yang ada di Palabuhanratu dan juga sangat bagus untuk bermain surfing.

Berikut ini adalah data jumlah kepala keluarga dan jumlah penduduk Kecamatan Cikakak Palabuhanratu.

Tabel 1

\section{Data Jumlah Kepala Keluarga Dan Jumlah Penduduk Kecamatan Cikakak} Palabuhanratu

\begin{tabular}{|c|c|c|c|}
\hline No & Nama Desa & $\begin{array}{c}\text { Jumlah Kepala } \\
\text { Keluarga }\end{array}$ & $\begin{array}{c}\text { Jumlah } \\
\text { Penduduk }\end{array}$ \\
\hline 1. & CIKAKAK & 1.518 & 5.439 \\
\hline 2. & CIMAJA & 1.679 & 6.209 \\
\hline 3. & RIDOGALIH & 1.425 & 5.255 \\
\hline 4. & SUKAMAJU & 1.446 & 5.116 \\
\hline 5. & MARGALAKSANA & 1.032 & 3.511 \\
\hline 6. & SIRANARASA & 1.892 & 6.416 \\
\hline 7. & GANDASOLI & 608 & 2.239 \\
\hline 8. & CILEUNGSING & 794 & 2.710 \\
\hline 9. & CIRENDANG & 754 & 2.310 \\
\hline & JUMLAH & 11.148 & 39.205 \\
\hline
\end{tabular}

Sumber : Dari Kecamatan Cikakak Palabuhanratu

Sekitar tahun 1976 seorang wisatawan mancanegara dari Amerika yang bernama John Phillip datang ke Cimaja Sambil membawa papan surfing (surf board), dia tinggal 1 minggu di Lostmen Sari Raos. Sejak itulah Pantai Cimaja sudah terkenal sampai mancanegara dan bagaikan surga bagi para peselancar (surfer) mancanegara maupun lokal. Dengan jarak tempuh dari Jakarta ke Cimaja sekitar 120 kilometer dan dari Bandung mencapai 203 kilometer, membuat pantai ini mudah diakses oleh wisatawan. Dengan panorama pantai yang indah dan ombak yang besar membuat 
pantai ini menjadi tempat favorit bagi para peselancar. Banyak para surfer lokal dan mancanegara yang datang ke pantai ini.

Berikut ini adalah data pengunjung wisatawan nusantara dan wisatawan mancanegara yang berkunjung ke Pantai Cimaja

Tabel 2

\section{Data Pengunjung Wisatawan Nusantara dan Wisatawan Mancanegara Yang Berkunjung Ke Pantai Cimaja}

\begin{tabular}{|c|c|c|c|c|}
\hline NO & RINCIAN & $\begin{array}{c}2010 \\
(\%)\end{array}$ & $\begin{array}{c}2011 \\
(\%)\end{array}$ & $\begin{array}{c}2012 \\
(\%)\end{array}$ \\
\hline 1. & Wisnus & 10.233 & 11.357 & 14.798 \\
& & $(26,43 \%)$ & $(28,68 \%)$ & $(33,66 \%)$ \\
\hline 2. & Wisman & 28.493 & 28.689 & 29.153 \\
& & $(73,57 \%)$ & $(71,31 \%)$ & $(66,33 \%)$ \\
\hline 3. & Jumlah & 38.726 & 40.226 & 43.951 \\
& & $(100 \%)$ & $(99,99 \%)$ & $(99,99 \%)$ \\
\hline
\end{tabular}

Sumber : Dari DISPARBUDPORA Kabupaten Sukabumi

Pantai Cimaja mendunia dengan ombak kanan yang konsisten sehingga peselancar dari belahan dunia berdatangan ingin mencobanya. Setiap tahun, pada bulan juni-juli digelar kejuaraan surfing (selancar) level internasional dengan tema West Java Open Championship. Suatu kebanggaan Pantai Cimaja, Palabuhanratu, Sukabumi, Jawa Barat dikenal di dunia internasioal. Kontur pantai yang berbeda dengan pantai pada umumnya, menjadikan Pantai Cimaja sebagai objek wisata pantai yang memiliki daya tarik dikunjungi. Di sepanjang pantai berhiaskan bebatuan kali yang berbentuk bulat. Hal ini pula yang menjadikan Cimaja mengantongi predikat Bali-nya Sukabumi.

Pariwisata pada saat ini cenderung menjadi kebutuhan seluruh lapisan masyarakat, baik yang melakukan perjalanan wisata maupun masyarakat sekitar daerah tujuan wisata. Wisatawan butuh dipuaskan keinginannya, sementara masyarakat sekitar lokasi berharap akan mendapatkan implikasi positif berupa peningkatan pendapatan dan kesejahteraan. Fenomena ini harus menjadi perhatian para penentu kebijakan sebagaimana diamanatkan oleh DISPARBUDPORA Kabupaten Sukabumi, bahwa pembangunan kepariwisataan nasional diarahkan menjadi sektor andalan dan unggulan secara luas akan diterjemahkan sebagai penghasilan devisa terbesar yang akan mendorong pertumbuhan ekonomi, meningkatkan pendapatan daerah, memberdayakan perekonomian masyarakat, memperluas lapangan kerja dan kesempatan berusaha.

Pembangunan yang berpusat pada masyarakat lebih menekankan pada pemberdayaan (empowerment), yang memandang potensi masyarakat sebagai sumber daya utama dalam pembangunan dan memandang kebersamaan sebagai tujuan yang 
akan dicapai dalam proses pembangunan. Pemberdayaan masyarakat sangat di perlukan dalam pembangunan obyek wisata, dengan berprinsip pada pro job (kesempatan lapangan kerja). Salah satu manfaat terbesar dari pemberdayaan adalah memungkinkan pengembangan dan penggunaan bakat dan/atau kemampuan terpendam dalam diri setiap individu masyarakat. Bersamaan dengan fleksibilitas dan kebebasan kerja yang lebih besar diharapkan dapat memunculkan kemampuan kreatif dan inovatif masyarakat.

Pemberdayaan masyarakat diharapkan dapat meningkatkan perekonomian masyarakat, khususnya masyarakat asli (indigenous people) setempat yang berada disekitar atau dalam lokasi wisata Pantai Cimaja. Masyarakat dipandang dapat terlibat dan atau mampu menunjang dalam kegiatan pariwisata dalam bentuk penyediaan makanan dan minuman, tempat tinggal (homestay), pemandu (guide), sarana dan prasaran transportasi, penyewaan mobil atau motor, penyediaan penyewaan dan penjualan peralatan surfing. Dan juga sekaligus akan membuka peluang bagi home industry dalam bentuk kerajinan tangan, souvenir, dan lain sebagainya. Keterlibatan masyarakat dalam kegiatan pariwisata di Pantai Cimaja diharapkan akan mampu memberikan tambahan pendapatan masyarakat secara memadai.

Dari kegiatan masyarakat seperti Surf Shoop, Restoran, dan Hotel/Losmen yang ada di Pantai Cimaja, Desa Cimaja Kecamatan Cikakak Palabuhanratu. kebanyakan pemilik dari Surf Shoop, Restoran, dan Hotel/Losmen tersebut adalah milik orang asing atau orang lain yang bukan asli masyarakat Cimaja.

Juga terdapat KOMPEPAR (Komunitas Penggerak Pariwisata) dan Kurawa, Kurawa yaitu kelompok masyarakat Desa Cimaja yang menjadi pamandu (guide) para wisatawan. Hampir 90\% wisatawan (surfer) yang datang ke Desa Cimaja di pandu oleh masyarakat Desa Cimaja, untuk menawarkan jasa seperti mengantarkan ke Pantai Cimaja, penyewaan mobil dan motor, dan juga jasa-jasa yang lainnya. Untuk penyewaan mobil dan motor, hampir di setiap hotel/losmen meneyediakan fasilitas tersebut.

Pendekatan partisipatif yang melibatkan masyarakat setempat dalam pengelolaan sumberdaya alam agar dapat diupayakan peningkatan kesejahteraan masyarakat dengan cara perluasan kesempatan kerja disamping pengelolaan kekayaan laut yang didasarkan pada pemanfaatan sumberdaya secara optimal dan lestari, juga pada gilirannya akan mampu meningkatkan pendapatan masyarakat setempat.

Untuk menjadikan penelitian ini lebih terfokus, maka peneliti membatasi masalah yang akan diteliti adalah Pantai Cimaja, karena Pantai Cimaja terletak di Kecamatan Cikakak Palabuhanratu. Kecamatan Cikakak itu sendiri terdiri dari sembilan desa, maka yang akan diteliti oleh peneliti adalah Desa Cimaja dan Desa Cikakak, karena Pantai Cimaja terletak diantara dua desa tersebut yaitu Desa Cimaja dan Desa Cikakak.

Adapun tujuan dari penelitian ini adalah untuk mengetahui seberapa besar daya tarik wisata, pemberdayaan masyarakat serta pengaruhnya daya tarik wisata terhadap pemberdayaan masyaraka di Pantai Cimaja Cikakak Kabupaten Sukabumi. Selain itu, diharapkan penelitian ini dapat memberikan kontribusi bagi dinas Pariwisata 
Kabupaten Sukabumi untuk mengembangkan objek wisata yang ada di Pelabuhanratu (Pantai Cimaja), serta dapat meningkatkan perekonomian masyarakat desa Cimaja.

\section{KAJIAN PUSTAKA}

\section{Konsep Pariwisata}

Kata pariwisata berasal dari bahasa sansekerta yang artinya mereka yang meniggalkan rumah untuk mengadakan perjalanan tanpa mencari nafkah di tempat yang dikunjungi sambil menikmati kunjungan mereka (Pendit, 2003:1).

Pariwisata merupakan kegiatan perjalanan untuk rekreasi. Biasanya masyarakat mengunjungi tempat-tempat pariwisata yang menarik, mulai dari gunung, pantai, perkotaan, dll. Manusia modern sekarang ini menjadikan pariwisata sebagai kebutuhan pokok setelah disibukkan oleh urusan pekerjaan. Apalagi didukung oleh semakin banyaknya armada transportasi yang menawarkan tarif serta harga yang menarik dengan destinasi tertentu membuat masyarakat menjadi lebih bersemangat dalam berekreasi.

\section{Konsep Produk Wisata}

Suatu obyek wisata pasti mempunyai daya tarik wisata yang sangat menarik untuk dikunjungi oleh wisatawan. Daya tarik tersebut termasuk dalam produk wisata yang diantaranya ada atraksi wisata, amenitas (fasilias), dan juga aksesibilitas. Middleton (2001:122) memberikan pengertian produk wisata lebih dalam yaitu“The tourist products to be considered as an amalgam of three main components of attraction, facilities at the destination and accessibility of the destination". Dari pengertian di atas kita dapat melihat bahwa produk wisata secara umum terbentuk disebabkan oleh tiga komponen utama yaitu atraksi wisata, fasilitas di daerah tujuan wisata dan aksesibilitas.

Middleton (2001:124) mengungkapkan ada tiga komponen utama dari produk wisata yang dapat diuraikan sebagai berikut:

\section{a. Atraksi}

Elemen-elemen di dalam suatu atraksi wisata yang secara luas menentukan pilihan konsumen dan mempengaruhi motivasi calon-calon pembeli diantaranya:

1. Atraksi wisata Alam, meliputi bentang alam, pantai, iklim dan bentukan geografis lain dari suatu destinasi dan sumber daya alam lainnya.

2. Atraksi wisata buatan / Binaan Manusia, meliputi angunan dan infrastruktur pariwisata termasuk arsitektur bersejarah dan modern, monument, trotoar jalan, taman dan kebun, pusat konvensi, marina, ski, tempat kepurbakalaan, lapangan golf, toko-toko khusus dan daerah yang bertema. 
3. Atraksi Wisata Budaya, meliputi sejarah dan cerita rakyat (legenda), agama dan seni ,teater music, tari dan pertunjukkan lain, dan museum. Beberapa dari hal tersebut dapat dikembangankan menjadi even khusus, festival, dan karnaval.

4. Atraksi Wisata Sosial, meliputi pandangan hidup suatu daerah, penduduk asli, bahasa, dan kegiatan-kegiatan pertemuan sosial.

\section{b. Amenitas / Fasilitas}

Terdapat unsur-unsur di dalam suatu atraksi atau berkenaan dengan suatu atraksi yang memungkinkan pengunjung untuk menginap dan dengan kata lain untuk menikmati dan berpatisipasi di dalam suatu atraksi wisata. Hal tersebut meliputi :

1. Akomodasi meliputi hotel, desa wisata, apartment, villa, caravan, hostel, guest house, dansebagainya.

2. Restoran, meliputi dari makanan cepat saji sampai dengan makanan mewah.

3. Transportasi di suatu atraksi, meliputi taksi, bus, penyewaan sepeda dan alat ski di atraksi yang bersalju.

4. Aktivitas, seperti sekolah ski, sekolah berlayar dan klub golf.

5. Fasilitas-fasilitas lain, misalnya pusat-pusat bahasa dan kursus keterampilan.

6. Retail Outlet, seperti toko, agen perjalanan, souvenir, produsen camping.

7. Pelayanan-pelayanan lain, misalnya salon kecantikan, pelayanan informasi, penyewaan perlengkapan dan kebijaksanaan pariwisata.

\section{c. Aksesibilitas}

Elemen-elemen ini adalah yang mempengaruhi biaya, kelancaran dan kenyamanan terhadap seorang wisatawan yang akan menempuh suatu atraksi. Elemen-elemen tersebut ialah :

1. Infrastruktur

2. Jalan, bandara, jalur kereta api, pelabuhan laut, marina.

3. Perlengkapan, meliputi ukuran, kecepatan, jangkauan dari sarana transportasi umum.

4. Faktor-faktor operasional seperti jalur/rute operasi, frekuensi pelayanan, dan harga yang dikenakan.

5. Peraturan Pemerintah yang meliputi pengawasan terhadap pelaksanaan peraturan transportasi.

\section{Wisatawan}

Komponen produk wisata itulah yang mendukung berjalannya suatu kegiatan pariwisata, dan juga sebagai fasilitas bagi wisatawan. Wisatawan adalah orang yang melakukan kegiatan pariwisata, Wisatawan menurut UN-WTO ( Cooper 2006, Ritchie and Goeldner 2003, Gee 1999 :7-8) memiliki tiga kelompok tujuan kunjungan, seperti berikut ini. 


\section{Leisure and recreation (vakansi dan rekreasi)}

Jenis kegiatan ini adalah segala kegiatan yang memiliki tujuan seperti; vakansi dan rekreasi, mengunjungi event budaya, kesehatan, olah raga aktif, dan tujuan liburan lain termasuk dalam kategori bersenang-senang. Kegiatan utama dalam kategori ini berupa kegiatan berjalan-jalan, keliling kota dan makan. Sementara itu, kegiatan pendukung dalam kategori ini berupa mengunjungi kerabat dan saudara, menghindari konferensi, berbisnis dan belanja. Wisatawan yang memiliki tujuan bersenang-senang dan rekreasi disebut sebagai wisatawan vakansi. Ada yang mengatur perjalanan sendiri, ada pula yang meminta bantuan biro perjalanan untuk mempersiapkan perjalanan. Ia bisa melakukan perjalanan ke manapun ia mau dan cenderung menyebar ke seluruh dunia selama daerah tujuan wisata memiliki keunikan dan sesuatu yang dalam memenuhi kebutuhan wisata. Tema perjalanan bisa beragam mulai dari alam, budaya, hingga olahraga (nonprofesional).

2. Business and professional (bisnis dan profesional)

Ada beberapa tujuan kunjungan dalam kategori bisnis dan profesional diantaranya adalah rapat, misi, perjlanan intensif dan bisnis. Tujuan-tujuan itu berhubungan erat dengan pekerjaan. Perjalanan yang dilakukan tidak untuk mencari nafkah, tetapi kegiatannya berdampak pada pekerjaannya. Wisatawan dengan tujuan bisnis dan profesional disebut dengan wisatawan bisnis. Ia memiliki tujuan perjalanan untuk rapat, menjalankan misi, perjalanan intensif, dan bisnis. Kegiatan utamanya berkaitan dengan konsultasi, konveksi dan inspeksi. Sementara itu, kegiatan pendukungnya berupa makan, menikmati hiburan, rekreasi, belanja, berjalanan dan mengunjungi saudara serta kerabat.

Wisatawan bisnis selalu menggunakan jasa biro perjalanan untuk mengatur perjalanan. Ia memiliki jadwal perjalanan yang sangat padat dan ketat. Pilihan tempat wisatanya terstruktur dan cenderung terpusat pada kota-kota besar.

\section{Other tourism purposes (tujuan wisata lain)}

Wisata lain yang dimaksud, diantaranya seperti belajar, pemulihan kesehatan, transit dan berbagai tujuan lain yang termasuk dalam kategori tujuan wisata. Tujuan lain diantaranya melakukan kunjungan kepada kerabat dan saudara, melakukan ziarah, melakukan perjalanan keagamaan atau religi, melakukan widya wisata (kegiatan wisata sambil belajar). Kegiatan yang dilakukan dengan tujuan tersebut diantaranya menambah wawasan dan pengetahuan, melakukan pemeriksaan kesehatan bersosialisasi, dan mempertebal keimanan

\section{Pemberdayaan Masyarakat}

Pariwisata pada saat ini cenderung menjadi kebutuhan seluruh lapisan masyarakat, baik yang melakukan perjalanan wisata maupun masyarakat sekitar daerah tujuan wisata. Wisatawan butuh dipuaskan keinginannya, sementara masyarakat sekitar lokasi berharap akan mendapatkan implikasi positif berupa peningkatan pendapatan dan kesejahteraan. 
Untuk itu pemberdayaan masyarakat sangat diperlukan dalam memajukan obyek wisata. Carlzon dan Macauley sebagaimana dikutip oleh Wasistiono (1998:46) mengemukakan bahwa yang dimaksud dengan pemberdayaan adalah sebagi berikut: "membebaskan seseorang dari kendali yang kaku, dan memberi orang kebebasan untuk bertanggung jawab terhadap ide-idenya, keputusan-keputusannya dan tindakantidakanya."

\section{Pro Job (Kesempatan Lapangan Kerja)}

Dari pemberdayaan masyarakat tersebut diharapkan dapat membuka kesempatan lapangan kerja baru bagi masyarakat asli setempat dan juga dapat meningkatkan perekonomian masyarakat setempat yang berada di sekitar atau dalam lokasi wisata. Sukirno (2000: 68), memberikan pengertian kesempatan kerja sebagai suatu keadaan dimana semua pekerja yang ingin bekerja pada suatu tingkat upah tertentu akan dengan mudah mendapat pekerjaan.

Dari definisi di atas, maka kesempatan kerja apat dibedakan menjadi dua golongan yaitu

a. Kesempatan kerja permanen yaitu kesempatan kerja yang memungkinkan orang bekerja secara terus-menerus sampai mereka pensiun atau tidak mampu lagi untuk bekerja. Misalnya adalah orang yang bekerja pada instansi pemerintah atau swasta yang memiliki jaminan sosial hingga hari tua dan tidak bekerja ditempat lain.

b. Kesempatan kerja temporer yaitu kesempatan kerja yang memungkinkan seseorang bekerja dalam waktu yang relatif singkat, kemudian menganggur untuk menunggu kesempatan kerja baru. Misalnya adalah orang yang bekerja sebagai pegawai lepas pada perusahaan swata dimana pekerja mereka tergantung order.

Sehingga ketersediaan lapangan kerja yang memadai bagi rakyat, serta terpenuhinya kebutuhan dasar pangan, pakaian, dan papan, dapat terwujud dengan sebaik-baiknya. Oleh karena itu pendekatan Pro Job (kesempatan lapangan kerja) adalah suatu pendekatan yang sangat tepat.

\section{METODE PENELITIAN}

\section{Objek Penelitian}

Penenlitian ini dilakukakan di Pantai Cimaja yang bertempat di Desa Cimaja Cikakak Kecamatan Cikakak Kabupaten Sukabumi Provinsi Jawa Barat. Difokuskan pada Daya Tarik Wisata Pantai Cimaja dan Pemberdayaan Masyarakat Desa Cimaja. Daya Tarik Wisata Pantai Cimaja sebagai independent variable (variabel bebas X), sedangkan Pemberdayaan Masyarakat sebagai dependent variable (variabel terikat Y). 
Adapun populasi dari penelitian ini adalah wisatawan yang berkunjung ke Pantai Cimaja dan 2 Desa, yaitu Desa Cimaja dan Desa Cikakak. Adapun data jumlah wisatawan yang berkunjung ke Pantai Cimaja pada tahun 2012 yang diperoleh dari Dinas Pariwisata Kabupaten Sukabumi dan untuk data jumlah masyarakat Desa Cimaja dan Desa Cikakak di peroleh dari Kecamatan Cikakak. Adapun untuk sampel dalam penelitian ini adalah 100 wisatawan dan 100 masyarakat dari Desa Cimaja dan Desa Cikakak. Untuk teknik sampling yang digunakan adalah teknik accidental sampling adalah teknik penentuan sampel berdasarkan kebetulan yaitu siapa saja yang secara kebetulan bertemu dengan peneliti dapat digunakan sebagai sampel.

\section{Metode Penelitian}

Metode penelitian yang digunakan oleh penulis berdasarkan atas tujuan penelitiannya. Penelitian ini terdiri dari tiga tujuan. Tujuan penelitian pertama, Untuk mengetahui seberapa besar daya tarik wisata di Pantai Cimaja Cisolok Kabupaten Sukabumi, menggunakan metode penelitian deskriptif dengan tipe penelitian kualitatif (Churcill \& Iacobucci 2005: 74). Tujuan penelitian kedua, yaitu untuk mengetahui seberapa besar pemberdayaan masyarakat di Pantai Cimaja Cisolok Kabupaten Sukabumi, menggunakan metode penelitian deskriptif dengan tipe penelitian kualitatif (Churcill \& Iacobucci 2005: 74). Tujuan penelitian ketiga, yaitu untuk mengukur seberapa besar pengaruh daya tarik wisata terhadap pemberdayaan masyarakat di Pantai Cimaja Cisolok Kabupaten Sukabumi, menggunakan metode penelitian assosiatif dengan tipe penelitian kualitatif dan kuantitatif Sugiono (2012: 36). Waktu pengumpulan data dilakukan pada suatu kurun waktu (cross sectional), sebagai gambaran situasi, keadaan, atau kegiatan pada saat itu (Ruslan, 2003:30).

\section{HASIL DAN PEMBAHASAN}

\section{Analisi Daya Tarik Wisata}

Tujuan penelitian pertama, untuk mengetahui seberapa besar daya tarik wisata di Pantai Cimaja Cisolok Kabupaten Sukabumi, menggunakan metode penelitian deskriptif. Analisis deskriptif data penelitian dapat digunakan untuk memperkaya pembahasan, melalui analisis ini dapat diketahui bagaimana tanggapan responden terhadap setiap indikator variabel yang sedang diteliti. Agar lebih mudah menginterpretasikan variabel yang sedang diteliti, maka dilakukan kategorisasi terhadap skor tanggapan responden. Prinsip kategorisasi jumlah skor tanggapan responden diadopsi dari teori Sugiyono (2007), yaitu berdasarkan rentang skor maksimum dan skor minimum, kemudian dibagi jumlah kategori yang diinginkan dengan rumus sebagai berikut.

$$
\text { Rentang Skor Kategori }=\frac{\text { Skor Maksimum }- \text { Skor Minimum }}{5}
$$


Keterangan :

Skor maksimum $=$ jumlah responden $\mathrm{x}$ jumlah pernyataan $\mathrm{x} 5$

Skor minimum $=$ jumlah responden $\mathrm{x}$ jumlah pernyataan $\mathrm{x} 1$

Dari 100 responden yang diteliti diperoleh jawaban mengenai variabel Daya Tarik Wisata sebagai berikut:

Tabel 7

Skor Jawaban Responden Mengenai Item-item Pernyataan Variabel Daya Tarik Wisata (X)

\begin{tabular}{|c|c|c|c|c|c|c|}
\hline \multicolumn{7}{|c|}{ Daya Tarik Wisata (X) } \\
\hline \multirow{2}{*}{ Instrumen } & $\begin{array}{c}\text { Sangat } \\
\text { Baik (5) }\end{array}$ & Baik (4) & $\begin{array}{c}\text { Cukup } \\
\mathbf{( 3 )}\end{array}$ & $\begin{array}{c}\text { Kurang } \\
\mathbf{( 2 )}\end{array}$ & $\begin{array}{c}\text { Sangat } \\
\text { Kurang } \\
(\mathbf{1})\end{array}$ & Skor \\
\hline 1 & 52 & 44 & 4 & 0 & 0 & 448 \\
\hline 2 & 48 & 47 & 5 & 0 & 0 & 443 \\
\hline 3 & 18 & 65 & 17 & 0 & 0 & 401 \\
\hline 4 & 5 & 47 & 40 & 8 & 0 & 349 \\
\hline 5 & 39 & 43 & 16 & 2 & 0 & 419 \\
\hline 6 & 7 & 61 & 28 & 4 & 0 & 371 \\
\hline 7 & 0 & 1 & 39 & 37 & 23 & 218 \\
\hline 8 & 8 & 55 & 34 & 3 & 0 & 368 \\
\hline 9 & 19 & 53 & 26 & 2 & 0 & 389 \\
\hline 10 & 7 & 29 & 47 & 16 & 1 & 325 \\
\hline 11 & 11 & 57 & 30 & 2 & 0 & 377 \\
\hline 12 & 1 & 12 & 33 & 35 & 19 & 241 \\
\hline 13 & 0 & 16 & 55 & 21 & 8 & 279 \\
\hline 14 & 4 & 49 & 37 & 8 & 2 & 345 \\
\hline 15 & 0 & 1 & 33 & 37 & 29 & 206 \\
\hline & $\mathbf{2 1 9}$ & $\mathbf{5 8 0}$ & $\mathbf{4 4 4}$ & $\mathbf{1 7 5}$ & $\mathbf{8 2}$ & \\
\cline { 1 - 6 } Total & $\mathbf{( 2 1 9 \times 4 ) =}$ & $\mathbf{( 5 8 0 x 4 ) =}$ & $\mathbf{( 4 4 4 x 3 ) =}$ & $\mathbf{( 1 7 5 x 2 ) =}$ & $\mathbf{( 8 2 x 1 ) =}$ & $\mathbf{5 1 7 9}$ \\
\hline $\mathbf{1 0 9 5}$ & $\mathbf{2 3 2 0}$ & $\mathbf{1 3 3 2}$ & $\mathbf{3 5 0}$ & $\mathbf{8 2}$ & \\
\hline
\end{tabular}

Sumber : olah data kuisioner, Agustus 2013

Pada variabel Daya Tarik Wisata dengan jumlah item pernyataan 15 butir dan jumlah responden (wisatawan) 100 orang, diperoleh total skor sebesar 5179, maka rentang skor setiap kategori ditentukan sebagai berikut.

Rentang Skor Kategori $=\frac{(100 \times 15 \times 5)-(100 \times 15 \times 1)}{5}$ 


$$
=\frac{7500-1500}{5}=1200
$$

Jadi, panjang interval untuk setiap kategori adalah 1200, sehingga dari jumlah skor tanggapan responden atas 15 butir pernyataan mengenai Daya Tarik Wisata diperoleh rentang sebagai berikut.

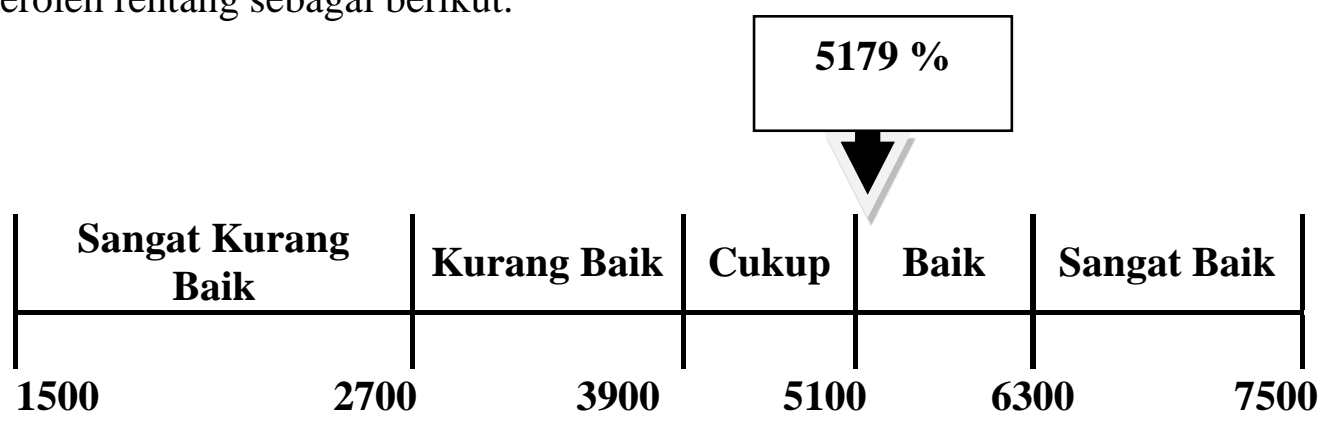

Melalui jumlah skor tanggapan responden dari 15 pernyataan yang diajukan mengenai variabel Daya Tarik Wisata, maka dapat diketahui bahwa tanggapan responden mengenai Daya Tarik Wisata termasuk dalam kategori "baik".

\section{Analisis Pemberdayaan Masyarakat}

Tujuan penelitian kedua, untuk mengetahui seberapa besar pemberdayaan masyarakat di Pantai Cimaja Cisolok Kabupaten Sukabumi, menggunakan metode penelitian deskriptif. Analisis deskriptif data penelitian dapat digunakan untuk memperkaya pembahasan, melalui analisis ini dapat diketahui bagaimana tanggapan responden terhadap setiap indikator variabel yang sedang diteliti. Agar lebih mudah menginterpretasikan variabel yang sedang diteliti, maka dilakukan kategorisasi terhadap skor tanggapan responden. Prinsip kategorisasi jumlah skor tanggapan responden diadopsi dari teori Sugiyono (2009), yaitu berdasarkan rentang skor maksimum dan skor minimum, kemudian dibagi jumlah kategori yang diinginkan dengan rumus sebagai berikut.

Rentang Skor Kategori $=\frac{\text { Skor Maksimum }- \text { Skor Minimum }}{5}$

Keterangan :

Skor maksimum $=$ jumlah responden $\mathrm{x}$ jumlah pernyataan $\mathrm{x} 5$

Skor minimum = jumlah responden $\mathrm{x}$ jumlah pernyataan $\mathrm{x} 1$

Dari 100 responden (masyarakat) yang diteliti diperoleh jawaban mengenai sub variabel Pemberdayaan Masyarakat sebagai berikut: 
Tabel 8

Skor Jawaban Responden Mengenai

Item-item Pernyataan Variabel Pemberdayaan Masyarakat (Y)

\begin{tabular}{|c|c|c|c|c|c|c|}
\hline \multicolumn{7}{|c|}{ Pemberdayaan Masyarakat (Y) } \\
\hline Instrumen & $\begin{array}{c}\text { Sangat } \\
\text { Setuju } \\
(5)\end{array}$ & $\begin{array}{c}\text { Setuju } \\
\text { (4) }\end{array}$ & $\begin{array}{c}\text { Ragu- } \\
\text { Ragu } \\
\text { (3) }\end{array}$ & $\begin{array}{c}\text { Tidak } \\
\text { Setuju } \\
\text { (2) }\end{array}$ & $\begin{array}{c}\text { Sangat } \\
\text { Tidak } \\
\text { Setuju (1) }\end{array}$ & Skor \\
\hline 1 & 50 & 43 & 5 & 0 & 2 & 439 \\
\hline 2 & 68 & 27 & 3 & 2 & 0 & 461 \\
\hline \multirow[b]{2}{*}{ Total } & 118 & 70 & 8 & 2 & 2 & \multirow[b]{2}{*}{900} \\
\hline & $\begin{array}{c}(118 \times 5)= \\
590\end{array}$ & $\begin{array}{c}(70 \times 4)= \\
280\end{array}$ & $\begin{array}{c}(8 \times 3)= \\
24\end{array}$ & $\begin{array}{c}(2 \times 2)= \\
4\end{array}$ & $(2 \times 1)=2$ & \\
\hline
\end{tabular}

Sumber : olah data kuisioner, Agustus 2013

Pada sub variabel Pemberdayaan Masyarakat dengan jumlah item pernyataan 2 butir dan jumlah responden (masyarakat) 100 orang, diperoleh total skor sebesar 900, maka rentang skor setiap kategori ditentukan sebagai berikut.

Rentang Skor Kategori $=\frac{(100 \times 2 \times 5)-(100 \times 2 \times 1)}{5}$

$$
=\frac{1000-200}{5}=160
$$

Jadi, panjang interval untuk setiap kategori adalah 160, sehingga dari jumlah skor tanggapan responden atas 2 butir pernyataan mengenai Pemberdayaan Masyarakat diperoleh rentang sebagai berikut.

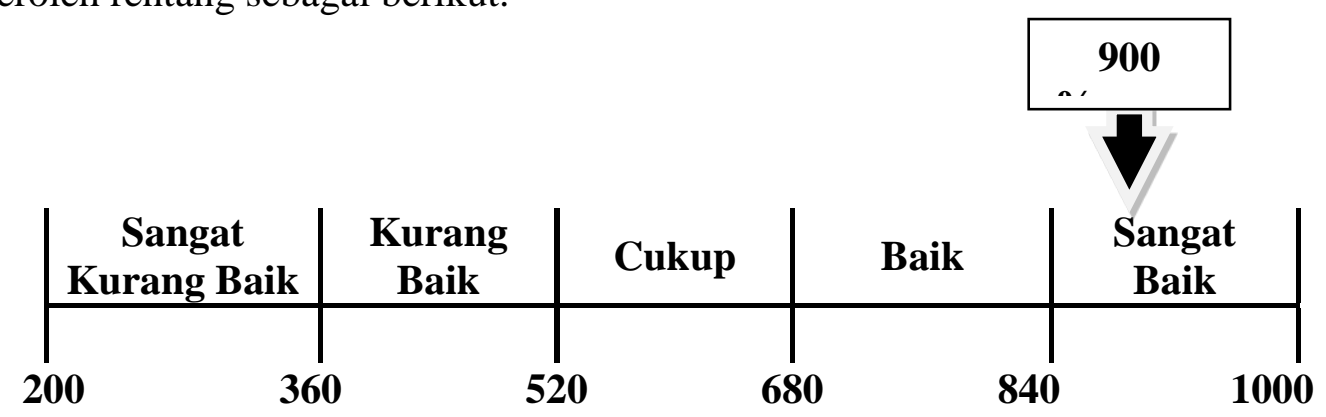

Melalui jumlah skor tanggapan responden dari 2 pernyataan yang diajukan mengenai sub variabel Pemberdayaan Masyarakat, maka dapat diketahui bahwa tanggapan responden mengenai Pemberdayaan Masyarakat termasuk dalam kategori "sangat baik". 


\section{Analisis Pengaruh Daya Tarik Wisata Terhadap Pemberdayaan Masyarakat}

\section{a. Regresi Linear Berganda}

Analisis regresi berganda adalah suatu analisis yang digunakan untuk meramalkan begaimana keadaan (naik turunnya) variabel dependen, bila dua atau lebih variabel independen sebagai faktor prediktor dinaik turunkan nilainya (Sugiyono : 275).

Pada penelitian ini, analisis regresi berganda dimaksudkan untuk mengetahui adanya pengaruh antara Atraksi Wisata $\left(X_{1}\right)$, Amenitas (fasilitas) $\left(X_{2}\right)$ dan Aksesibilitas $\left(\mathrm{X}_{3}\right)$ terhadap Pemberdayaan Masyarakat (Y). Tujuannya untuk meramalkan atau memperkirakan nilai variabel dependen dalam hubungan sebabakibat terhadap nilai variabel lain.

Model regresi berganda yang akan dibentuk adalah sebagai berikut:

$\mathrm{Y}=\mathrm{a}+\mathrm{b}_{1} \mathrm{X}_{1}+\mathrm{b}_{2} \mathrm{X}_{2}+\mathrm{b}_{3} \mathrm{X}_{3}+\mathrm{e}$

Dimana:

$\mathrm{Y}=$ Variabel Pemberdayaan Masyarakat

$\mathrm{X}_{1} \quad=$ Variabel Atraksi Wisata

$\mathrm{X}_{2} \quad=$ Variabel Amenitas (fasilitas)

$\mathrm{X}_{3} \quad=$ Variabel Aksesibilitas

$\mathrm{b}_{1,2,3} \quad=$ Koefisien regresi

a $\quad=$ Bilangan konstanta / intercept

e $\quad=$ error

Dengan menggunakan bantuan aplikasi program SPSS, didapat output hasil perhitungan regresi linier berganda sebagai berikut:

Tabel 9

Hasil Perhitungan Nilai Koefisien Persamaan Regresi

Coefficients

\begin{tabular}{|c|c|c|c|c|c|c|}
\hline \multirow{2}{*}{\multicolumn{2}{|c|}{ Model }} & \multicolumn{2}{|c|}{$\begin{array}{l}\text { Unstandardized } \\
\text { Coeff icients }\end{array}$} & \multirow{2}{*}{$\begin{array}{l}\text { Standardized } \\
\text { Coeff icients }\end{array}$} & \multirow[b]{2}{*}{$\mathrm{t}$} & \multirow[b]{2}{*}{ Sig. } \\
\hline & & B & Std. Error & & & \\
\hline & (Constant) & 7,313 & 1,041 & & 7,025 &, 000 \\
\hline & $\mathrm{X} 1$ &,- 095 & ,063 &,- 170 & $-1,501$ & 137 \\
\hline & $\times 2$ & ,050 & ,045 & 145 & 1,111 & 269 \\
\hline & $X 3$ &,- 015 & ,085 &,- 021 &,- 179 & 858 \\
\hline
\end{tabular}

a. Dependent Variable: $Y$

Berdasarkan output di atas didapat nilai kontstanta dan koefisien regresi sehingga dapat dibentuk persamaan regresi linier berganda sebagai berikut:

$\mathrm{Y}=7,313-0,095 \mathrm{X}_{1}+0,050 \mathrm{X}_{2}-0,015 \mathrm{X}_{3}$

Persamaan di atas dapat diartikan sebagai berikut: 
$\mathrm{a}=7,313$, artinya jika Atraksi Wisata $\left(\mathrm{X}_{1}\right)$, Amenitas (fasilitas) $\left(\mathrm{X}_{2}\right)$ dan Aksesibilitas $\left(\mathrm{X}_{3}\right)$ bernilai nol (0), maka Pemberdayaan Masyarakat (Y) akan bernilai 7,313 satuan.

$\mathrm{b}_{1}=-0,095$, artinya jika Atraksi Wisata $\left(\mathrm{X}_{1}\right)$ meningkat sebesar satu satuan dan variabel lainnya konstan, maka Pemberdayaan Masyarakat (Y) akan menurun sebesar 0,095 satuan.

$\mathrm{b}_{2}=0,050$, artinya jika Amenitas (fasilitas) $\left(\mathrm{X}_{2}\right)$ meningkat sebesar satu satuan dan variabel lainnya konstan, maka Pemberdayaan Masyarakat (Y) akan meningkat sebesar 0,050 satuan.

$b_{3}=-0,015$ artinya jika Aksesibilitas $\left(X_{3}\right)$ meningkat sebesar satu satuan dan variabel lainnya konstan, maka Pemberdayaan Masyarakat (Y) akan menurun sebesar 0,015 satuan.

\section{b. Analisis Korelasi Pearson Product Moment}

Analisis korelasi Pearson Product Moment adalah suatu analisis yang digunakan untuk mencari hubungan dan membuktikan hipotesis hubungan dua atau lebih variabel bila data variabel berbentuk interval atau rasio dan sumber data dari masingmasing variabel adalah sama (Sugiyono: 228). Dengan menggunakan bantuan aplikasi program SPSS didapat output hasil koefisien korelasi sebagai berikut:

Tabel 10

Nilai Koefisien Korelasi PearsonProduct Moment

Model Summary

\begin{tabular}{|l|r|r|r|r|}
\hline Model & $\mathrm{R}$ & $\mathrm{R}$ Square & $\begin{array}{c}\text { Adjusted } \\
\mathrm{R} \text { Square }\end{array}$ & $\begin{array}{c}\text { Std. Error of } \\
\text { the Estimate }\end{array}$ \\
\hline 1 &, $164^{\mathrm{a}}$ &, 027 &,- 004 & 1,53158 \\
\hline
\end{tabular}

a. Predictors: (Constant), X3, X1, X2

Dari analisis diatas dapat diketahui bahwa nilai koefisien korelasi (R) adalah sebesar 0,164. Nilai tersebut kemudian diintepretasikan berdasarkan kriteria Guilford sebagai berikut:

Tabel 11

Koefisien Korelasi dan Taksirannya

\begin{tabular}{|c|c|}
\hline Interval Koefisien & Tingkat Hubungan \\
\hline $0,00-0,199$ & Sangat Rendah \\
$0,20-0,399$ & Rendah \\
$0,40-0,599$ & Sedang \\
$0,60-0,799$ & Kuat \\
$0,80-1,000$ & Sangat Kuat \\
\hline
\end{tabular}

Sumber :Sugiyono, 2009:231 
Berdasarkan tabel interpretasi koefisien korelasi yang disajikan di atas, maka koefisien korelasi sebesar 0,164 menunjukkan adanya hubungan yang sangat rendah antara variabel bebas secara simultan dengan variabel terikat.

\section{c. Analisis Koefisien Determinasi}

Analisis koefisien determinasi adalah suatu analisis yang digunakan untuk mengetahui pengaruh dari suatu variabel terhadap variabel lainnya. Koefisien determinasi adalah kuadrat dari koefisien korelasi (Sugiyono : 231). Setelah diketahui nilai $\mathrm{R}$ sebesar 0,164, maka koefisien determinasi dapat dihitung menggunakan rumus sebagai berikut:

Tabel 12

\section{Analisis Koefisien Determinasi}

Model Summary
\begin{tabular}{|l|r|r|r|r|}
\hline Model & R & R Square & $\begin{array}{c}\text { Adjusted } \\
\text { R Square }\end{array}$ & $\begin{array}{r}\text { Std. Error of } \\
\text { the Estimate }\end{array}$ \\
\hline 1 &, $164^{\mathrm{a}}$ &, 027 &,- 004 & 1,53158 \\
\hline
\end{tabular}

a. Predictors: (Constant), X3, X1, X2

$$
\begin{aligned}
\mathrm{KD} & =\mathrm{R}^{2} \times 100 \% \\
& =(0,164)^{2} \times 100 \%=2,7 \%
\end{aligned}
$$

Dengan demikian, maka diperoleh nilai koefisien determinasi sebesar 2,7\% yang menunjukkan arti bahwa Atraksi Wisata $\left(\mathrm{X}_{1}\right)$, Amenitas (fasilitas) $\left(\mathrm{X}_{2}\right)$ dan Aksesibilitas $\left(\mathrm{X}_{3}\right)$ memberikan pengaruh simultan (bersama-sama) sebesar 2,7\% terhadap Pemberdayaan Masyarakat (Y). Sedangkan sisanya sebesar 97,3\% dipengaruhi oleh faktor lain yang tidak diamati di dalam penelitian ini.

Untuk mengetahui persentase pengaruh dari masing-masing variabel bebas terhadap Pemberdayaan Masyarakat (Y), maka digunakan rumus Koefisien Beta $\times$ Zero-order, dengan hasil sebgai berikut :

\section{Tabel 13}

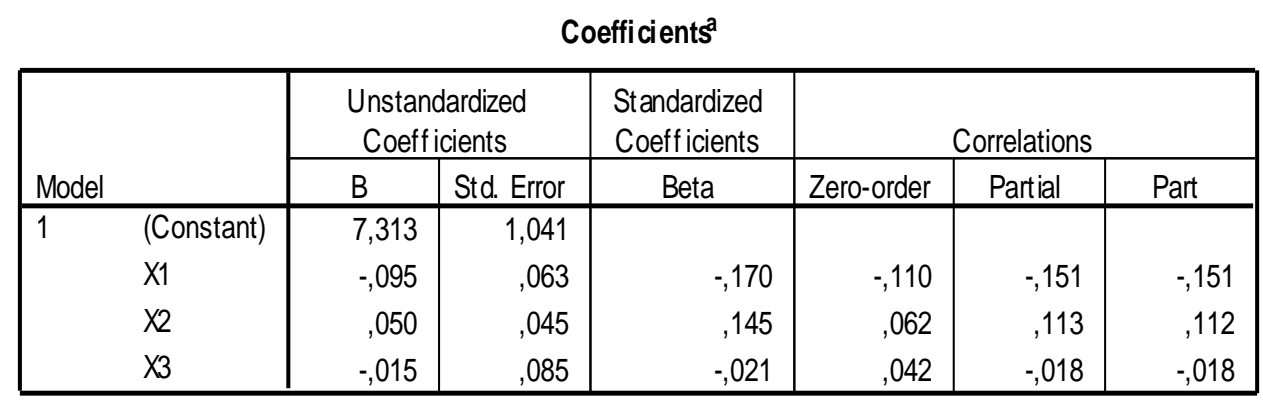

a. Dependent Variable: $Y$ 
1. Variabel $\mathrm{X}_{1}=(-0,170) \times(-0,170)=0,0187=1,87 \%$

2. Variabel $\mathrm{X}_{2}=0,145 \times 0,062=0,0090=0,90 \%$

3. Variabel $\mathrm{X}_{3}=(-0,021) \times 0,042=-0,0009=-0,09 \%$

Dengan demikian, tidak ada hubungan yang kuat antara daya tarik wisata dengan pemberdayaan masyarakat, karena dari dua desa yang diteliti yaitu Desa Cimaja dan Desa Cikakak dengan jumlah kepala keluarga 3197, hanya 2,7 \% yang ikut terlibat langsung dalam kegiatan pariwisata di Pantai Cimaja sedangkan sisanya adalah keterlibatan dari desa lain dan bahkan ada dari luar kabupaten sukabumi yang terilbat di dalam kegiatan pariwisata di Pantai Cimaja.

\section{SIMPULAN DAN SARAN}

\section{SIMPULAN}

Setelah dilakukan serangkaian pengumpulan data, pengolahan data, penyebaran kuesioner dan pengujian hipotesis dengan tujuan untuk mengetahui pengaruh daya tarik wisata terhadap pemberdayaan di Pantai Cimaja Cikakak, maka dapat diambil kesimpulan sebagai berikut :

1. Daya Tarik Wisata di Pantai Cimaja Cikakak termasuk dalam kategori "baik". Hal ini dapat dilihat dari tanggapan responden (wisatawan) yang menilai bahwa Atraksi Wisata yang ada di Pantai Cimaja Cikakak dalam kategori "baik", juga dengan Amenitas (fasilitas) yang di diberikan kepada wisatawan dalam kategori "cukup", dan untuk Aksesibilitas menuju Pantai Cimaja Cikakak dalam kategori "cukup". Pantai Cimaja dinilai menarik dan memotivasi para wisatawan untuk berkunjung ke Pantai Cimaja yang memiliki ombak sangat bagus untuk berselancar (surfing) bagi para wisatawan.

2. Pemberdayaan Masyarakat di Pantai Cimaja Cikakak termasuk dalam kategori "sangat baik". Hal ini dapat dilihat dari tanggapan responden (masyarakat) yang menilai bahwa dengan adanya pariwisata di Pantai Cimaja Cikakak dapat memberikan kesempatan lapangan kerja baru dan juga dapat meningkatkan pendapatan masyarakat Desa Cimaja dan Desa Cikakak.

3. Pengaruh daya tarik wisata terhadap pemberdayaan masyarakat di pantai cimaja cikakak dapat dilihat dari hasil berikut :

a. Nilai koefisien regresi berganda yang memperlihatkan terdapat pengaruh antara Atraksi Wisata $\left(\mathrm{X}_{1}\right)$ terhadap Pemberdayaan Masyarakat (Y), namun tidak signifikan yaitu sebesar $-0,095$, juga terdapat pengaruh antara Amenitas (fasilitas) $\left(\mathrm{X}_{2}\right)$ terhadap Pemberdayaan Masyarakat (Y), namun tidak signifikan yaitu sebesar 0,050, dan terdapat pengaruh antara 
Aksesibilitas $\left(\mathrm{X}_{3}\right)$ terhadap Pemberdayaan Masyarakat $(\mathrm{Y})$ namun tidak signifikan yaitu sebesar $-0,015$.

b. Koefisiean determinasi sebesar $2,7 \%$ yang menunjukkan arti bahwa Atraksi Wisata $\left(\mathrm{X}_{1}\right)$, Amenitas (fasilitas) $\left(\mathrm{X}_{2}\right)$ dan Aksesibilitas $\left(\mathrm{X}_{3}\right)$ memberikan pengaruh simultan (bersama-sama) sebesar 2,7\% terhadap Pemberdayaan Masyarakat (Y). Sedangkan sisanya sebesar 97,3\% dipengaruhi oleh faktor lain, faktor lain tersebut bisa jadi bahwa sebagian besar masyarakat Desa Cimaja dan Desa Cikakak tidak ikut langsung terlibat dalam pariwisata yang ada di pantai Cikakak.

\section{SARAN}

Setelah menyimpulkan penelitian ini seara keseluruhan saran yang dapat diberikan peneliti pada pemberdayaan masyarakat di Pantai Cimaja Cikakak yaitu:

1. Pantai Cimaja merupakan pantai yang sangat bagus karena memiliki pemandangan yang sangat indah dan juga ombak yang sangat bagus untuk berselancar (Surfing). Saran yang ingin diberikan peneliti berdasarkan pengamatan pribadi. Peneliti menyarankan kepada Dinas Pariwisata Kabupaten Sukabumi dan Masyarakat Desa Cimaja dan Desa Cikakak lebih menjaga kebersihan Pantai, karena dari hasil kuisioner penelitian berdasarkan tanggapan responden (wisatawan) untuk kebersihan Pantai Cimaja masih sangat kotor. Dan menurut tanggapan responden (wisatawan) untuk aksesibilitas menuju Pantai Cimaja juga masih sangat jelek, dan itu merupakan peran Pemerintah Dinas Pariwisata Kabupaten Sukabumi untuk membenahi aksesibilitas tersebut, karena dengan aksesibilitas yang bagus dapat memudahkan para wisatawan untuk berkunjung ke Pantai Cimaja.

2. Saran kedua yang ingin diberikan oleh peneliti berdasarkan penelitian yang telah dilaksanakan. Peneliti menyarankan kepada Dinas Pariwisata Kabupaten Sukabumi lebih sering memberikan penyuluhan tentang pariwisata, karena dari hasil wawancara yang saya lakukan ternyata sebagian besar masyarakat Desa Cimaja dan Desa Cikakak masih belum mengerti banyak tentang pariwisata dan belum sadar akan wisata, sehingga masih sedikit masyarakat yang terlibat langsung dalam kegiatan pariwisata di Pantai Cimaja. Dan itu merupakan tugas yang sangat berat yang harus dilakukan Pemerintah Dinas Pariwisata Kabupaten Sukabumi supaya masyarakat Desa Cimaja dan Desa Cikakak mengerti tentang Pariwisata.

3. Saran ketiga yang ingin diberikan oleh peneliti berdasarkan penelitian yang telah dilaksanakan. Peneliti menyarankan kepada Kepala Dinas Pariwisata Kabupaten Sukabumi dan KOMPEPAR Desa Cimaja dan Desa Cikakak untuk lebih sering mengadakan penyuluhan-penyuluhan tentang pariwisata, karena dari hasil penelitian yang peneliti lakukan ternyata hasil dari 
"Pengaruh Daya Tarik Wisata Terhadap Pemberdayaan Di Pantai Cimaja Cikakak Kabupaten Sukabumi" masih sangat kecil pengaruhnya dan masyarakat yang berdaya dalam kegiatan pariwisata masih sedikit dikarenakan masih banyak masyarakat yang belum mengerti tentang feed back yang dihasilkan dari kegiatan pariwisata di Pantai Cimaja. Dengan memberikan penyuluhan tentang pariwisata, di harapkan banyak masyarakat yang mengerti dan paham dengan apa yang akan di berikan dari pariwisata tersebut. Dan dengan keterlibatan masyarakat di dalam kegiatan pariwisata tersebut bisa memperoleh lapangan pekerjaan baru dan meningkatkan pendapatan masyarakat Desa Cimaja dan masyarakat Desa Cikakak.

\section{DAFTAR PUSTAKA}

Aaker, D, K, V. \& Day, G, S. (2004). Marketing Research. New York: John Wiley $\&$ Sons.

Esmara, H. (1986). Sumber Daya Manusia, Kesempatan Kerja Dan Perkembangan Ekonomi. UI Press. Jakarta.

Suwantoro, G. (2004). Dasar-Dasar Pariwisata: Andi Taufik \& Muhammad; Yogyakarta.

Huraerah, A. (2008), Pengorganisasian Dan Pengembangan Masyarakat; Model Dan Strategi Pembengunan Berbasis Kerakyatan; Penyunting, Mety Melawati; Humaniora, Bandung.

Hikmat, R. H. (2001), Strategi Pemberdayaan Masyarakat; Kusnaka Adimiharja; Humaniora Utama, Bandung.

Istijanto. (2005), Riset Sumber Daya Manusia; Agus Purwanto; PT Gramedia Pustaka Utama, Jakarta.

James J, S. (2003). Ekonomi Pariwisata. Kanisius; Yogyakarta.

Kesrul, M. (2003). Pokok-Pokok Masalah Penguatan Pariwisata Alam Dikawasan Pedesaan Alam. Kanisius; Yogyakarta.

Kusmayadi. \& Sugiarto, E. (.....). Metodologi Penelitian Dalam Bidang Kepariwisataan Manusia Seutuhnya. Alumni Bandung.

Kotler, Brown, Makens (2009); Marketing for Hospitality and Tourism; Elsevier Ltd; Oxford UK. 
Middleton, V. (2001). Marketing In Travel And Tourism; A Division Of Reed Educational And Profesional Publishing. Ltd: Oxford UK.

Pendit, S. N. (2003), Seni Budaya; Falsafah, Agama Hindu, dan Pariwisata; Gramedia; Jakarta.

Riza, R, \& Roesmidi. (2006). Pemberdayaan Masyarakat; ALQAPRINT JATINANGOR; Sumedang.

Sagir, S. (1985). Kesempatan Kerja, Ketahanan Nasional Dan Pembangunan

Sihite, R. (2000). Tourism industry. Sic. Surabaya.

Sugiyono. (2007). Metode Penelitian Kuantitatif Kualitatif dan R\&D; Alfabeta; Bandung.

Sukirno. (2000). Pengantar Ekonomi Mikro. Erlangga: Jakarta.

UU No.10 2009 Tentang Kepariwisataan.

Wasistiono, S. (1998). Pemberdayaan Masyarakat dan jaring Pengaman Sosial. Gramedia; Jakarta. 